\title{
OFFSHORE TERRITORIES: POSITIVE AND NEGATIVE IMPACTS ON THE GLOBAL ECONOMY
}

\author{
Anna Tytko', Iryna Sukhan², Marianna Koshchynets ${ }^{3}$
}

\begin{abstract}
The aim of the article is to analyse and clarify the areas of development of offshore zones in the functioning of the world economic system. The subject of the study is offshore zones and offshore international centres as the locus of laundering of funds obtained by illegal means and their impact on the economy in total. Methodology. The study is based on the use of general scientific and special scientific methods in studying a coherent picture of development and possible trends in the further functioning of offshore zones in the global economic system. General scientific methods such as deduction, induction, analogy, analysis, synthesis enabled to reveal the implication of the world's offshore zones as a system for laundering illegally obtained funds. The comparative method enabled to distinguish the specific features of offshore zones and offshore international centres and to identify common and distinctive features. The prognostic method allowed forming an original outlook on the advantages and disadvantages of offshore activities. Logical-semantic and dogmatic methods enabled to define the concepts of "offshore jurisdiction", "offshore zone", "offshore financial centre" and their specific features. The results of the study enabled to consider offshore zones, offshore financial centres and international financial centres, in terms of their specific features, as certain territories and areas of certain states, where under the exclusive conditions of doing business outside the territory of registration, non-resident entities are granted benefits and privileges in doing business, taxation, registration, and financial reporting, as well as an exclusive privilege of confidentiality. Practical implications. In the study, first, the concepts of "offshore zone", "offshore financial centre", "international offshore centre" are defined; second, the scientific approaches to their classification are analysed and compared in the specialized literature, the Fifth Directive is considered as the main legal regulation of money laundering and the BEPS Project; third, the author's outlook on the positive and negative features of offshore activities and their impact on the world economy are substantiated. Relevance/originality. The author's approach to the definition of the main features of offshore zones and offshore financial centres through the analysis of their qualitative characteristics is offered to determine the key areas of their development trends.
\end{abstract}

Key words: financial system, offshore financial centre, offshore zone, offshore jurisdiction, black lists, grey lists, directive, money laundering.

\section{JEL Classification: 016, P34}

\section{Introduction}

It has been repeatedly emphasized that annually a system of well-established schemes of international offshore zones enables illegal withdrawal of large amounts of funds from the financial systems of each country. Due to the creation of offshore jurisdictions, in the global economic network, socalled "tax havens," the areas where capital operates freely and brings illegal proceeds to its owners, exist. The use of privileges and benefits of offshore zones, such as reduction of tax, currency and transaction control, and the confidentiality regarding the final beneficiary, confirms the relevance and necessity to study the activities of offshore zones and centres in their inextricable link, as well as their destructive impact on the economy of individual countries and the financial system in total. Therefore, this enables to avoid taxation and use such schemes of the illegal currency movement to extend the scale of shadow processes in the global economy.

At different times, the study of offshore activity and its impact on the development trends of the world economic system was undertaken by scholars, such as D. Meadows, J. Tobin, N. Shaxson, V. V. Virchenko, O. I. Borysov, A. M. Voronin, V. O. Virchenko, D. Yu. Holubkov, N. Yu. Koniakhin, M. V. Korolov, A. N. Mykhailyn, V. P. Leshchuk, D. Yu. Mamotenko, I. I. Nikitchuk, A. I. Ryzhkova, N. M. Teliuk and others.

\footnotetext{
Corresponding author:

${ }^{1}$ National Academy of Internal Affairs, Ukraine.

${ }^{2}$ Uzhhorod National University, Ukraine.

${ }^{3}$ National Academy of Internal Affairs, Ukraine.
} 
In view of the above, it is relevant to study the issue of delineating the definitions of offshore zone, offshore financial centre, offshore jurisdiction, as well as the impact of such territories functioning from the perspective of "money laundering", which is considered in this paper. In order to achieve this objective, the following tasks should be: first, to outline the delineation of the main definitions of offshore territories and make the appropriate classification; second, to analyse the development of offshore activities and international legislative regulation of offshore counteraction; third, to suggest original outlook on effects of the capital outflow through offshore territories on the world economy.

\section{Main material}

The experience of successful refinancing, avoiding the legal taxation system has become an integral part of the world economic community. According to Boston Consulting Group statistics, the total offshore funds increased from 6 trillion USD in 2005 to 10 trillion USD in 2016, so the offshore territories hide 10-13\% of world GDP (Ekonomisty pidrakhuvaly: v ofshorakh skhovano 10-13\% svitovoho VVP). The instability of the world economies, constant oil price fluctuation, and the financial and economic crisis lead to a revival of money laundering, furthermore, to expanding boundaries of the shadow economy. Thus, as of 2016, about 35-40 countries of the world or their entities are offshore zones, which contribution to world GDP is relatively small (only $1.22 \%$ ), while they account for about $60 \%$ of all financial transactions and $25 \%$ of the international movement capital in the world.

Considering the Financial Secrecy Index study, in 2018 , the global amount of illegal cross-border financial flows is estimated at 1-1.6 trillion USD per year, and the total assets of offshore jurisdictions and tax havens reach 32 trillion USD. According to the Organization for Economic Cooperation and Development (OECD), due to the existence of such offshore zones, up to 250 billion USD of tax revenues disappear from the financial system of the countries of the world (Naskilky populiarni v Ukraini ofshory).

According to the 2016 International Narcotics Control Strategy Report of the Anti-Money-Laundering Agency, the countries with the highest levels of money laundering are Russia, the United States, the United Kingdom, Germany, and France. The relevance of this problem is also due to the fact that only in 2018, in the European Union about 110 billion EUR were "laundered", equivalent to $1 \%$ of the total GDP of the European Union, as well as exacerbation of using offshore schemes in the legalization of incomes avoiding the tax system, which leads to the decreasing state budget revenues. Therefore, this article attempts to determine the impact of offshore territories as free economic space on the economies of the states locally and on the global economy in total, as well as defining the concept of "offshore financial centre" and "offshore jurisdiction".

The concept of an offshore zone originates from English "off-shore", which means "situated at sea some distance from the shore", "outside own territory, abroad." An offshore zone or offshore jurisdiction (this definition can also be found in the specialized literature) is one of the varieties of free economic zones characterized by the creation of a favourable monetary and fiscal regime, a high level of banking and commercial secrecy, and loyalty to state regulation. Therefore, an offshore zone includes territories with a low or zero tax rate for all or certain categories of income, a certain banking or commercial secrecy, and a minimum or complete absence of reserve requirements of the central bank, or limitations on the currency convertibility.

According to A. N. Mykhailin, an offshore zone is a financial centre that attracts capital by providing tax and other preferences to non-residents of the country who have registered business in the offshore territory (Mykhailyn, 2015). In addition, in the concept of "offshore financial centres" N. Yu. Koniakhin includes territories or states with an extremely preferential regime for registration, taxation and conduct of financial transactions for foreign companies and banks (Koniakhina, 2008).

Furthermore, the Business Dictionary refers to offshore financial centres (hereinafter referred to as the OFC) as territories of such countries as Anguilla, Antigua, Bahamas, Bahrain, Cayman Islands, Hong Kong, Isle of Man, Jersey, Lebanon, Luxembourg, The Netherlands, Antilles, Panama, Singapore and the United Arab Emirates (UAE), which administrations do not interfere at all or partially in the legislative regulation of business and financial activities. In addition, the OFC also offers very low or zero tax rates and provides telecommunication infrastructure (Business dictionary). In most cases, the OFC is identified with an international financial centre.

International organizations define the term "offshore financial centre" as a territory divided into so-called tax havens and countries with favourable taxation, with a broad-based capital market that has a preferential tax and currency regime (Encyclopedia of offshore: a practical guide, 2007).

According to I. M. Tovkun, the OFC should be regarded as a part of the territory of the state, within which companies of foreign residents are registered and entitled to trade, financial and other commercial transactions on preferential terms (Tovkun, 2013).

Therefore, it can be argued that the main difference between offshore centres and offshore zones is that the latter are a part of individual states with preferential tax, currency, customs or administrative regimes and the absence of production activity of a non-resident country. 
More practically, definition of the AFC can be interpreted as the centre where the bulk of the financial activity is an offshore party on both sides of the balance sheet (i.e. counterparties for most obligations and assets of financial institutions are non-residents), transactions are initiated elsewhere, and most of the institutions involved are controlled by non-residents.

Therefore, the main specific features of offshore territories are: 1) the primary orientation of business to a non-resident entity; 2) a favourable regulatory environment (low level of supervision, requirements and minimum disclosure); 3) schemes of low or zero taxation.

For example, in accordance with the classification of recognized international organizations FATF (Financial Action Task Force on money laundering) and FSF (Financial Stability Forum), the term "offshore financial centre" applies to territories with a developed capital market, preferential tax and currency regimes, and ignoring the recommendations of international financial institutions to improve international regulation and control of banking and financial currency systems (Business dictionary). Meanwhile, the OFC has a large amount of banking and insurance business on its territory, through which export-import transactions, operations with real estate, marine vessels, trust and consulting activities are carried out.

Offshore centres are larger in scale, infrastructure and production activities.

Therefore, the OFC usually include: jurisdictions with a relatively large number of financial institutions, primarily engaged in business with nonresidents;

financial systems with external assets and obligations that are inappropriate to domestic financial intermediation charged to finance national economies;

centres that provide some or all of the following services: low or zero taxation; moderate or easy financial regulation; bank secrecy and anonymity.

According to the functional determination, available activities and relevant financial and economic activities, the centres can be classified into:

International Financial Centres (London, New York, Tokyo), which include major international service centres that support large domestic economies with deep and liquid markets that borrow short-term nonresident loans and provide long-term loans to nonresidents, with the further reliable legislative and regulatory framework.

Regional financial centres (Hong Kong, Singapore, Luxembourg) are fundamentally different from international ones by small-scale domestic economies.

Conventional financial centres (Paris, Frankfurt, Tokyo, Sydney). This category can include financial centres providing services, primarily aimed at meeting the needs of their national economies, not regions or the world.
Offshore financial centres, as a rule, differ from centres with very limited resources to support financial intermediation. Such centres usually provide preferences, such as wide opportunities for global tax planning, and only then provide services of the international financial centre; minimal registration procedures; the adequate legal framework to ensure the integrity of relations between principals and agents countries; proximity to major economies or countries attracting capital inflows; freedom from exchange control; protection of assets from the influence of legal proceedings, etc.

Ya. A. Shabeikin argues that according to the scale and nature of preferences provided, the offshore centres should be classified into territories with:

- preferential taxation providing full tax avoidance related to incomes of companies registered in a donor country.

These territories are called tax havens (the Antilles, Bahamas, Bermuda, British Virgin Islands, Gibraltar, Cayman Islands, Isle of Man, Nauru, Turks, and Caicos). - moderate taxation, where the agreement on the abolition of double taxation is in force (Shabeikina, 2014).

In such territories, a minimum tax on profits is levied. In these countries, a favourable tax system, preferential terms for official offices have been created (Ireland, Switzerland, Luxembourg, Austria, the Netherlands, Antilles, Mauritius, Seychelles, Vanuatu, Madeira, Western Samoa, Saint Vincent, Cyprus, etc.).

The policy of investigating and countering offshore activities is implemented by a large number of international organizations, such as the most active Organization for Economic Cooperation and Development (OECD) and the Financial Action Task Force on Money Laundering (FATF).

In view of February 2018, information on bank scandals in Latvia, and then with the Maltese bank Pilatus and the Danske Bank affiliate in Estonia, the EU countries decided on the need to strengthen the control of the "money laundering" through offshore companies.

In light of these events, the Council of Europe adopted the Fifth Directive of May 4, 2018, which amended the current Directive no. 849 of 2015 (Piata Dyrektyva YeS rozshyriuie sferu diialnosti rehuliuiuchykh orhaniv Yevropeiskoho Soiuzu), among provisions of which the most important are enhancing transparency in the ownership of companies and trusts; improvement of transparency in information on beneficial ownership of companies and trusts; improvement of control over transactions involving high-risk third countries; providing extended powers to the European Union Financial Intelligence Units (FIU), especially in terms of free access to centralized registries of bank accounts and facilitating cooperation with national registries of Member States; preventing the risks of financing terrorism and money laundering when using 
anonymous prepaid cards and virtual currencies; protection of informers, who report money laundering, including the right to anonymity.

Some ways to regulate offshore flows include the following:

1. To conclude agreements on cooperation and exchange of information between countries with offshore zones and non-offshore countries.

2 . To include countries in the so-called "black" and "grey" lists of offshore jurisdictions (including in such a list entails various restrictions by non-offshore countries' regulators). The main criterion for including countries in such lists is the adoption of requirements for the disclosure of confidential information regarding any tax issues, its tax transparency, willingness to join the BEPS plan and the exchange of information. Thus, in 2016, the OECD included Costa Rica, Uruguay, Labuan and the Philippines in the blacklist. According to FATF information, such countries are Iran and the DPRK.

As of the end of 2017, the European Union published a "black list" (17 countries), which included American Samoa, Barbados, Bahrain, Grenada, Guam, Macao (PRC), Marshall Islands, Mongolia, Namibia, UAE, Palau, Panama, Samoa, Saint Lucia, Trinidad and Tobago, Tunisia, South Korea. Meanwhile, 47 countries and territories, including "classical" tax-free offshore (Belize, Bermuda, Cayman, Isle of Man, Seychelles, etc.) fell into the grey list.

3. To provide special restrictive measures, in particular, legislation on the taxation of dividends received by residents from controlled foreign corporations.

Therefore, it can be argued that offshore territories such as Cayman Islands, Panama, Tunisia, Seychelles and others plan to disclose the names of all nominee directors and managers of offshore companies. For example, Belize obliged foreign beneficiaries to hold innominate shares at the registrars. Meanwhile, the United States and other developed countries use many administrative regulations, strengthening the requirements for banks in terms of opening new accounts of offshore companies and control over the transactions of these suspect companies.

In order to regulate offshore activities, the BEPS (Base Erosion and Profit Shifting) Project, developed by the OECD with the active support of the G20 countries, has been introduced, the socalled Action Plan to address the problem of the tax base erosion and profit shifting. The content of this project as the main criterion for assigning any state to the "black list" is international cooperation to counter offshore processes, further recommendations for national authorities and their further implementation in the legislation of the countries. Any country ready to implement or create its own internal rules for regulating offshore operations can enter this project. The main areas of the Plan implementation are solving tax challenges and the peculiarities of taxation the digital economy; neutralization of so-called "hybrid schemes"; countering tax base erosion through the payment of interest and other financial transactions; general countering "harmful tax practices", considering the issue of transparency and substance; prevention of abusing the provisions of the agreements on the elimination of double taxation; prevention of schemes of artificial avoidance of the "permanent establishment" status; development of transfer pricing guidance for intangibles and transfer pricing in terms of risks and capital; development of transfer pricing guidance for other high-risk transactions; development of methods for collecting and analysing information on tax base erosion and profits shifting; introduction of rules for disclosure of "methods of aggressive tax planning"; optimization of transfer pricing documentation and accurate reporting; development and improvement of dispute resolution mechanisms on tax issues; development of a comprehensive multilateral convention on international taxation to modify ongoing tax treaties between countries (Plan BEPS).

The implication and scale of the world economy's offshore tendency is also evidenced by the information provided by the State Statistics Service (as of July 1, 2018), which states that the largest investment in the private sector of Ukraine came from Cyprus, up to 9.18 billion USD, $28.2 \%$ of total revenues for the 6 months of this year.

The number of foreign direct investments is 32.6 billion USD. The list of such countries includes Cyprus, the Netherlands, which share of the total investment is up to $21 \%$, Germany - up to $5.3 \%$, Switzerland - up to $4.7 \%$, the British Virgin Islands - up to $4.1 \%$.

Therefore, the greatest threat to the functioning of offshore centres and offshore zones is precisely in the privileges and preferences that these territories provide, such as: 1) the low level of taxation in offshore zones undermines the fiscal base of countries, residents of which use offshore services. According to the most conservative evaluations, the budgets of all countries of the world are deprived of at least 3 trillion USD hidden in offshore per year; 2) laundering illegally obtained funds contributes to increase of crime in all its manifestations, such as drug trafficking, trafficking in human beings, terrorist financing, and white-collar crime. Offshore centres and zones stimulate the shadowing of the economy and the expansion of international organized economic crime; 3 ) due to weak regulation of offshore financial operations, the risk of uncontrolled flows of so-called hot money increases, destabilizing the global financial system; 4) harmful tax competition, taking profits from onshore countries to create an element of instability in the global economy and finances owing to high potential accumulation of capital in offshore zones, especially speculative ones; 5) contribution to unstable trends in the world economy and the financial 
system due to the high potential accumulation of capital in offshore areas; 6) stimulation of negative social and economic situation in donor countries; 7) intensification of capital withdrawals, leading to exacerbation of the shadow economy, and reduction of social and industrial infrastructure development; 8) granting unjustified privileges and preferences to individual companies, leading to unfair competitive conditions for mediumsized businesses.

Despite a number of negative aspects of doing business through offshore zones and offshore financial centres, this scheme has enough advantages, such as: 1) activating cross-border financial flows and accelerating the circulation of financial assets internationally; 2) stimulating financial flows and creating conditions for diversification of investments; 3) increasing access to loans and better capital transformation, the incentive to reduce the level of tax pressure, which causes deepening of international financial flows; 4) reducing the risk of expropriation and ensuring protection of property rights, which, in turn, can activate economic growth, primarily in donor countries, promoting the prosperity of those states where offshore zones are located.

This contributes to the more harmonious development of the global economy in general, the competitiveness of companies at the national and global levels through the use of more flexible development strategies.
We support the viewpoint of Yu. P. Hrihorieva, that the main reasons for the withdrawal of capital offshore are the unfavourable internal environment for doing business, corruption, high exchange risks, business criminalization, and imperfect tax and currency legislation (Hryhorieva, 2016).

\section{Conclusions}

Therefore, the activity of offshore centres and offshore zones in general is very negative for the development of the world economy, but primarily offshore territories are an advantageous place to hide and withdraw illegally proceeds from illegitimate activity, in particular, international criminal activity. A step-by-step study of offshore activities enables to avoid financial risks at an early stage of doing business, to improve the situation on the domestic market for developing countries; in addition, an analysis of the shortcomings in the work of offshore companies will improve the legislation of countries in terms of exchange legislation. The main area of countering tax base erosion and profit shifting, as well as money laundering prevention, should be the urgent implementation of the EU Fifth Directive 2015/849 to enhance transparency in identifying true beneficiaries of offshore companies and trusts' owners, under open access to the registers of beneficial owners of legal entities and trust registered in all EU Member States.

\section{References:}

Ekonomisty pidrakhuvaly: v ofshorakh skhovano 10-13\% svitovoho VVP [Economists' assessment: $10-13 \%$ of world GDP is hidden in the offshore territories]. Retrieved from: https://glavcom.ua/news/ ekonomisti-pidrahuvali-v-ofshorah-shovano-10-13-svitovogo-vvp-451450.html (in Ukrainian)

Naskilky populiarni v Ukraini ofshory [How popular are offshore territories in Ukraine]. Retrieved from: https://biz.nv.ua/ukr/experts/cherkashyn/naskilki-populjarni-v-ukrajini-ofshori-2454606.html (in Ukrainian)

Mykhailyn, A. N. (2015). Slovnyk po zovnishnoekonomichnii diialnosti: uchbovyi posibnyk [Dictionary of foreign economic activity: a teaching manual]. M.: ALLA-PRINT. (in Ukrainian)

Koniakhina, N. Yu. (2008). «Off-shores» - osobennosti funktsionirovaniia v strukture osobykh ekonomicheskikh zon [Offshores - features of functioning in the structure of special economic zones]. Vestnyk Tambovskoho unyversiteta, 12, 412. (in Russian)

Business dictionary. Retrieved from: http://www.businessdictionary.com/definition/offshore-financial-centreOFC.html

Encyclopedia of offshore: a practical guide (2007). London. Zurich Boston: Finance Research Group.

Tovkun, I. M. (2013). Mizhnarodno-pravovi zasoby funktsionuvannia ofshornykh tsentriv [International legal means of functioning of offshore centres]. Problemy zakonnosti, 123, 49. (in Ukrainian)

Shabeikina, Ya. A. (2014). Ofshorni kompanii yak metod optymizatsii opodatkuvannia [Offshore companies as a method of tax optimization]. Science Time, 4-4, 284-290. (in Ukrainian)

Piata Dyrektyva YeS rozshyriuie sferu diialnosti rehuliuiuchykh orhaniv Yevropeiskoho Soiuzu [EU Fifth Directive expands the scope of the activities of the regulatory bodies of the European Union]. Retrieved from: https://offshorewealth.info/deofshorization/fifth-directive-widenes-area-of-activity-regulating-eu/ (in Ukrainian) Plan BEPS: konets epokhi agressivnoho nalohovoho planirovaniia [BEPS plan: the end of an aggressive tax-planning era]. Retrieved from: https://www.nexus.ua/plan-beps-konets-epokhi-agressivnogo-nalogovogo-planirovaniya (in Russian) Naybilshe investytsii v Ukrainu nadiishlo $\mathrm{z}$ ofshoriv [The largest investment in Ukraine came from offshore] (State Statistics). Retrieved from: https://hromadske.ua/posts/z-pochatku-roku-naibilshe-investytsii-v-ukrainunadiishlo-z-ofshoriv-derzhstat (in Ukrainian)

Hryhorieva, Yu. P. (2016). Deoffshoryzatsiia v systemi zovnishnoekonomichnykh interesiv RF [De-offshorization in the system of foreign economic interests of the Russian Federation] (Dissertation of Candidate of Economic Sciences (PhD) in specialty 08.00.14.). (in Ukrainian) 